\title{
精密工学会 アフィリエイト
}

\section{アフィリエイト通信}

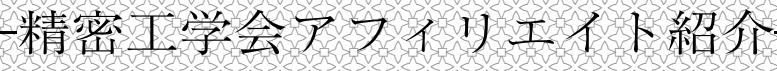

【精密工学会アフィリエイトとは】精密工学会では, 将来の精密工学を担う若手研究者・技術者の活性化を目的として, アフイリエイト制度を創設し，精密工学分野に扔ける学術活動，実用化技術開発抢よび本学会の発展に顕著な業績が見 込まれる若手研究者・技術者をアフィリエイトに認定しております。毎号 3 名ずつアフィリエイトメンバをご紹介しま す。皆様の御支援と御指導をよろしく㹉願い申し上げます。

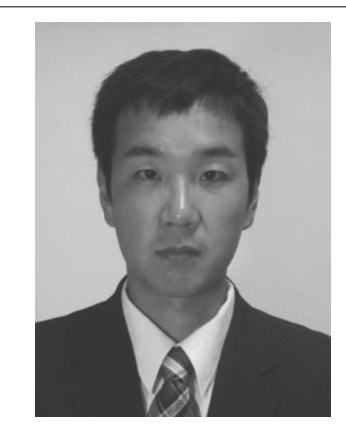

伊達宏昭 (Hiroaki DATE)

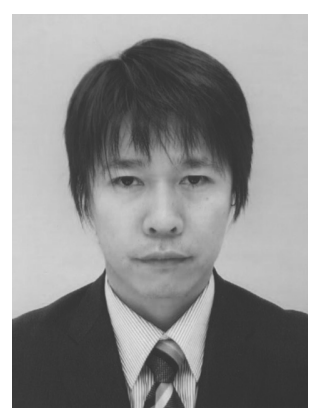

勝田智宣

(Tomonori KATSUTA)

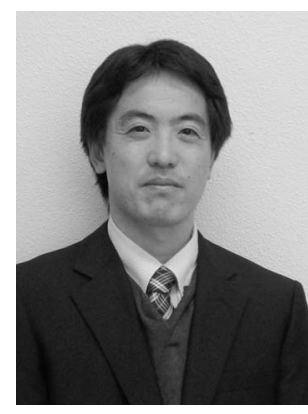

吉満真一 (Shinichi YOSHIMITSU)
Keywords：形状モデリング，形状計測データ処理， CAD/CAE

3 次元形状処理・モデリングに関する研究を行っています，現在は，非接触形状計測デー 夕の有効活用のための中・長距離レーザ計測データからの物体認識や X 線 CT 計測デー夕 の $\mathrm{CAE}$ 応用, $\mathrm{CAD} / \mathrm{CAE}$ 連携のための設計/解析用メッシュモデリング技術，より容易な 3 次元形状モデル利用のための 3 次元ユーザインタフェースシステムの開発等の研究を進め ています。ものづくりに打いてさまざまな 3 次元形状デー夕を面白く有効に活用すること を考えています。

ものを大切にする心を忘れずに，現在から未来のものづくりに貢献できる研究と教育を 目指しています，趣味はランニングで，出張先各地で走るのが最近の楽しみの一つです．

北海道大学 大学院情報科学研究科 システム情報科学専攻 准教授

厂060-0814 札幌市北区北 14 条西 9 丁目

TEL:011-706-6447 FAX:011-706-7120 E-mail :hdate@ssi.ist.hokudai.ac.jp

Keywords : 超精密加工, 超精密測定, 電子ビーム加工

研磨加工を用いない鏡面創成に関する技術開発に取り組んでいます。超精密旋盤と単結 晶ダイヤモンド工具を用いて，素粒子望遠鏡に用いる $\phi 600 \mathrm{~mm}$ の大型ミラーや $\phi 370 \mathrm{~mm}$ の非球面レンズ, 小型広視野カメラに用いる $\phi 10 \mathrm{~mm}$ 未満のミラーなど, 特殊な光学部品 の開発を行ってきました，また，大面積電子ビーム照射によって，チ夕ンのようなインプ ラント材料の一括鏡面仕上げの研究も行っています，機器を導入すれば簡単にできるわけ ではなく，ものづくりにはノウハウや泥臭い作業が非常に重要だと実感しています.

第 2 期アフィリエイトに任命されたのも束の間，2010 年1月から電気自動車のプロジェ クトを推進するようにお達しがあり, 岡山を離れ, 東京に異動になっています. そのため, 残念ながら研究や学会活動は開店休業状態ですが, よろしくお願いします.

岡山県工業技術センター 研究員

テ701-1296 岡山県岡山市北区芳賀 5301

TEL : 086-286-9600 FAX : 086-286-9630 E-mail : tomonori_katsuta@pref.okayama.lg.jp

Keywords : 加工監視，加工制御，モニタリング

生産システムに抄ける加工中の監視・計測技術は，高品質なものづくりへの要求に応え るための一つの要素として, 重要な役割を果たしています. 私どもの研究では, 切削加工 に打ける工具の挙動を可視化技術により捉え，加工監視技術として提案することに取り組 んでいます，加工状態の特徴量を捉え，工具の破損や破断の前兆を明らかにすることで効 率的な加工に寄与することができればと考えています，特に小径工具を用いた加工におい ては, 強度の問題から機械加工中の破損が問題となりますので，有効なモニタリング手法 を提案できるよう取り組んでいるところです.

高専は研究のみならず，担任業務やクラブ活動など教育に関してのウェイトも大きい職 場です. 授業や卒業研究, 部活動の指導など, 若さあふれる学生からエネルギ一をもらい ながら, 曰々奮闘しています。

鹿児島工業高等専門学校 電子制御工学科 助教

干 899-5193 鹿览島県霧島市隼人町真孝 1460-1

TEL : 0995-42-9089 FAX : 0995-42-9089 E-mail : yosimitu@kagoshima-ct.ac.jp 